\title{
A faunivorous early sphenacodontian synapsid with a diastema
}

\author{
Frederik Spindler
}

\begin{abstract}
Our knowledge on early sphenacodontian and edaphosaurid synapsids, the group that includes the origin of the mammalian lineage, largely arose from the Pennsylvanian Garnett locality in Kansas. A preliminary revision of the former "Haptodus" garnettensis found a greater diversity in the assigned material. The most striking deviation from the documented osteology is seen in a specimen comprising a lacrimal and associated maxilla. The diagnosis of this new form, Kenomagnathus scottae gen. et sp. nov., comprises a tall and shortened facial region, only two precanine teeth, and a distinct diastema. This is the oldest known diastema in synapsid evolution, and the first reported from a faunivorous member that lacks a precanine step, aside from Tetraceratops. This unique precanine morphology occurred independently from similar structures in Sphenacodontoidea. As for the edaphosaurid Gordodon, a specialized function in food processing is assumed for the diastema.
\end{abstract}

Frederik Spindler. Dinosaurier Museum Altmühltal, Dinopark 1, 85095 Denkendorf, Germany. mail@frederik-spindler.de

Keywords: pelycosaur; dentition; adaptation; new genus; new species.

Submission: 14 August 2019. Acceptance: 14 January 2020.

\section{INTRODUCTION}

In the late Paleozoic, synapsids were the dominant amniotes and evolved a great spectrum of adaptations, starting in the Carboniferous. During the last years, new descriptions included unexpected morphologies that dramatically increase the understanding of synapsid ecological success (Spindler et al., 2018, 2019b). The recent discovery of a large diastema in Gordodon (Lucas et al., 2018) exhibits a highly specialized autapomorphy within the Edaphosauridae that provides an insight into previously hidden morphological diversity of this herbivorous lineage. Traditionally, the only long and straight diastema in an early Permian synapsid was known from Tetraceratops,

http://zoobank.org/F789C37F-8167-4E64-AD6F-FFFA69B10B70

Spindler, Frederik. 2020. A faunivorous early sphenacodontian synapsid with a diastema. Palaeontologia Electronica, $23(1): a 01$. https://doi.org/10.26879/1023

palaeo-electronica.org/content/2020/2905-early-sphenacodontian-diastema

Copyright: January 2020 Society of Vertebrate Paleontology.

This is an open access article distributed under the terms of the Creative Commons Attribution License, which permits unrestricted use, distribution, and reproduction in any medium, provided the original author and source are credited.

creativecommons.org/licenses/by/4.0 
apparently a carnivore, and emphatically suspected to be the oldest therapsid. Since a number of therapsids possesses a diastema, this was counted as a potentially mammal-like trait. However, the oldest known diastema was discovered in a faunivorous or omnivorous haptodontine-grade sphenacodontian (Spindler, 2015) from the Pennsylvanian fauna of Garnett, Kansas, a synapsidrich paralic lagerstaette (Reisz et al., 1982). Although only two cranial elements are preserved, it shows a unique combination of tooth shape, skull architecture, and the rare diastema. The new form is herein presented in an updated description, along with a discussion of the significance of diastemata throughout the early evolution of synapsids.

Terminological note: As the presence of canines and their relative position close to the growth center of the maxilla can be traced throughout synapsid evolution, this is herein tentatively treated as homology from basal forms to mammals. Therefore, no straight distinction between caniniforms and canines is attended. Identification of canines in early synapsids is more related to increased size than to morphology. From a functional perspective, less pronounced teeth of the canine positions, referred to as caniniforms, do not work like true canines. This makes the terms more vague, but also underlines their genetically stable position in the maxillary tooth row.

\section{Institutional abbreviation}

ROM = Royal Ontario Museum, Toronto, Canada

\section{SYSTEMATIC PALEONTOLOGY}

SYNAPSIDA Osborn, 1903

HAPTODONTIFORMES Spindler, Werneburg,

Schneider, Luthardt, Annacker, and Rößler, 2018

SPHENACODONTIA Romer and Price, 1940

(sensu Reisz, Berman, and Scott, 1992)

Kenomagnathus gen. nov.

zoobank.org/3E2CC10B-2857-4481-90E4-BFA923ABB611

Type and only known species. Kenomagnathus scottae, sp. nov.

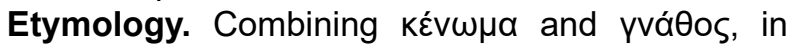
Greek 'gap' and 'jaw', in regard to the maxillary diastema.

Differential diagnosis. Early synapsid with a maxillary diastema followed by two precanines, two large canines, and at least 14 postcanines; canines and anterior postcanines tall, nearly straight, with moderate bulb and stout tip bearing striations; precanine margin lacking a concave step; tall lacrimal. Distinct from "Haptodus" garnettensis on basis of taller facial blades of the lacrimal and maxilla, less postcanine and precanine teeth, the convex precanine margin, presence of diastema, and shorter contribution of maxilla to naris. The diagnosis of Sphenacodontia based on node apomorphies is subject to an ongoing debate (Spindler, 2019), however, the assignment of ROM 43608 to Sphenacodontia is confirmed by the presence of stout marginal teeth, a convex ventral margin of the maxilla, and tall lacrimal and maxillary dorsal lobe. ROM 43608 is excluded from Sphenacodontoidea due to the narial contribution of the lacrimal.

Kenomagnathus scottae sp. nov. zoobank.org/9E68AFF8-8581-4020-81A3-2C8FFB50BFF4

Etymology. To honor Diane Scott, preparator at the Reisz lab, Mississauga, University of Toronto, who greatly helped with teaching and specimen handling, and also inspired this study.

Holotype. ROM 43608, disarticulated but associated maxilla and lacrimal (Figures 1,2). The specimen was originally labelled as Haptodus garnettensis (Laurin, 1993, figure 5 A). Additional preparation of the precanine margin after the reevaluation as a distinct taxon was carried out by $D$. Scott in 2013.

Holotype locality. Putnam Township, Garnett, Kansas, USA (Reisz et al., 1982).

Stratigraphic horizon and age. Carbonaceous, calcareous mudstone in the Rock Lake Shale Member of the Stanton Formation (Lansing Group), Missourian, Upper Pennsylvanian (late Carboniferous).

\section{Description}

The toothed margin of the maxilla is robust and more strongly convex than in "Haptodus" garnettensis, with a palatine sutural surface that appears to reach further anterior than in ROM 43606 (Spindler, 2015, figure 4.13). The canines are placed more anteriorly, resulting from the shortness of the maxilla compared to other early Haptodontiformes. There is a modest medial supracanine buttress and one even weaker in the posterior region. The anterior end of the maxilla is clearly indicated by the sutural facet to overlap the premaxilla. The antero-dorsal margin of the dorsal blade is steeply inclined. Therefore, the nostril architecture would not be the same as in "Haptodus" garnettensis.

Regarding the tooth curvature and striation, Kenomagnathus does not differ significantly from "Haptodus" garnettensis, although the bulb-like thickening near the tips looks rather pronounced, producing a blunter appearance. In contrast, tooth 


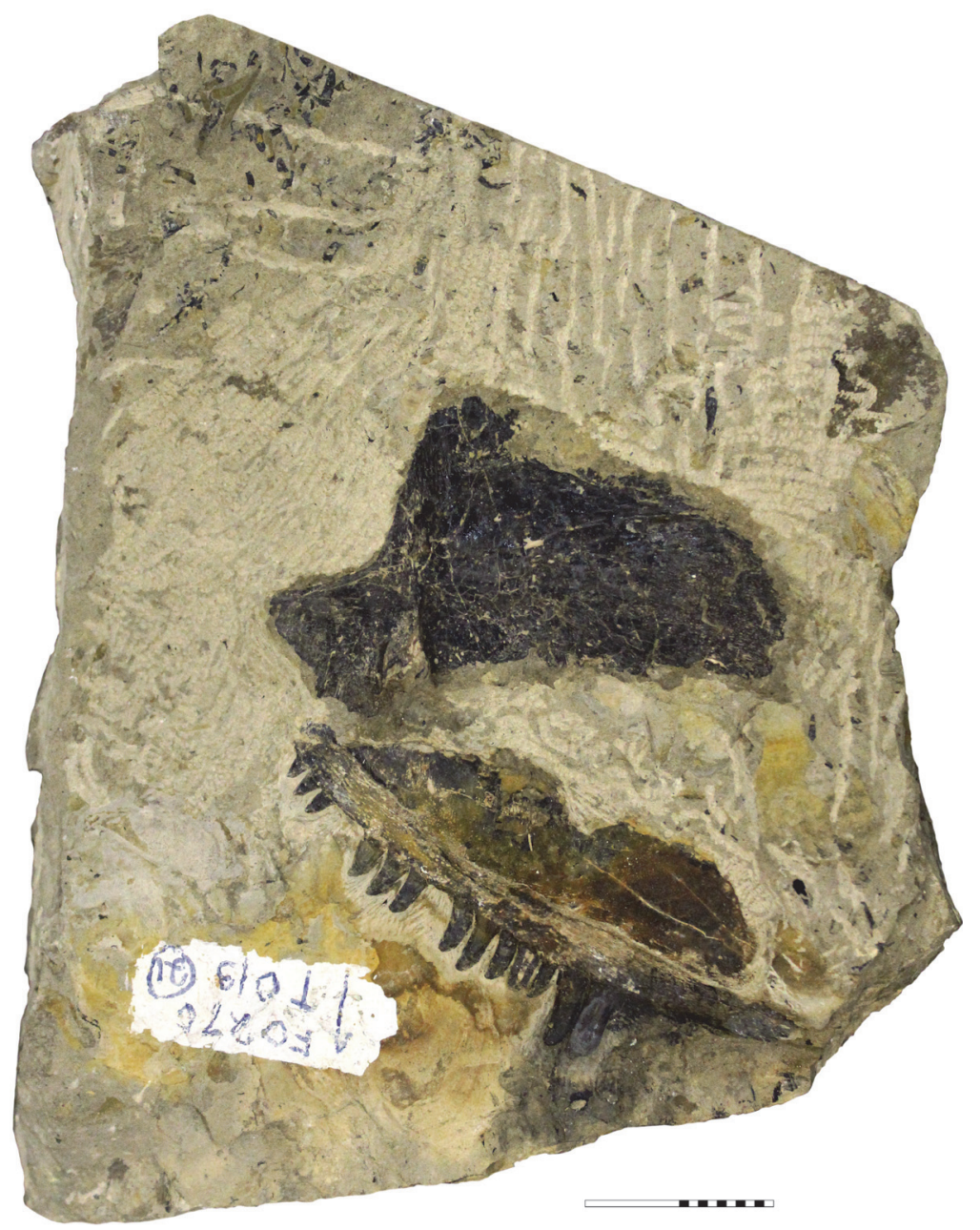

FIGURE 1. ROM 43608, holotype of Kenomagnathus scottae, gen. et sp. nov. Scale bar equals $2 \mathrm{~cm}$.

shafts are more slender in Kenomagnathus. There are two large canines or caniniforms and the bases of two broken precanines. Anterior to that, another indistinct shallow socket may reflect an additional, smaller tooth position, probably overgrown ontogenetically. Starting at this position and further anterior, a thinned ventral edge instead of a broad tooth margin indicates the presence of a diastema that covers the length of about three regular tooth positions (Figure 3). As the labial side of the diastema area was embedded in the host rock until the ventral margin was freed carefully, there is neither damage nor hidden bone substance that would debate this narrow edge. No precanine step interrupts the convexity of the ventral edge. There are 11 postcanine teeth preserved, with the gaps to account for 14 . In the posterior area, not much of the maxilla is missing, thus the postcanine number equals that of "Haptodus" garnettensis, while the maxilla extends less far posteriorly.
As the type of Kenomagnathus is the only Garnett specimen exposing the medial surface of the lacrimal, no detailed comparison is possible. In the anterior region, the outlet of the lacrimal duct is visible. From an ontogenetic point of view, the type of Kenomagnathus does not appear to be a very young juvenile. The lacrimal duct exposes its anterior outlet on the medial surface, whereas the juveniles of Palaeohatteria show a laterally exposed duct due to very incomplete ossification (Currie, 1979; Spindler, 2016).

The anterior expansion of the lacrimal would contribute to the narial rim with a tall area, resulting in a compact outline of the snout. Both the maxilla and lacrimal strongly resemble "Haptodus" garnettensis in general morphology but imply a taller skull (Figure 4). This is interpreted as reflecting a general condition of the skull, probably an adaption to a specialized diet or feeding behavior. Altogether, the short facial region, large orbits, and a maxillary 

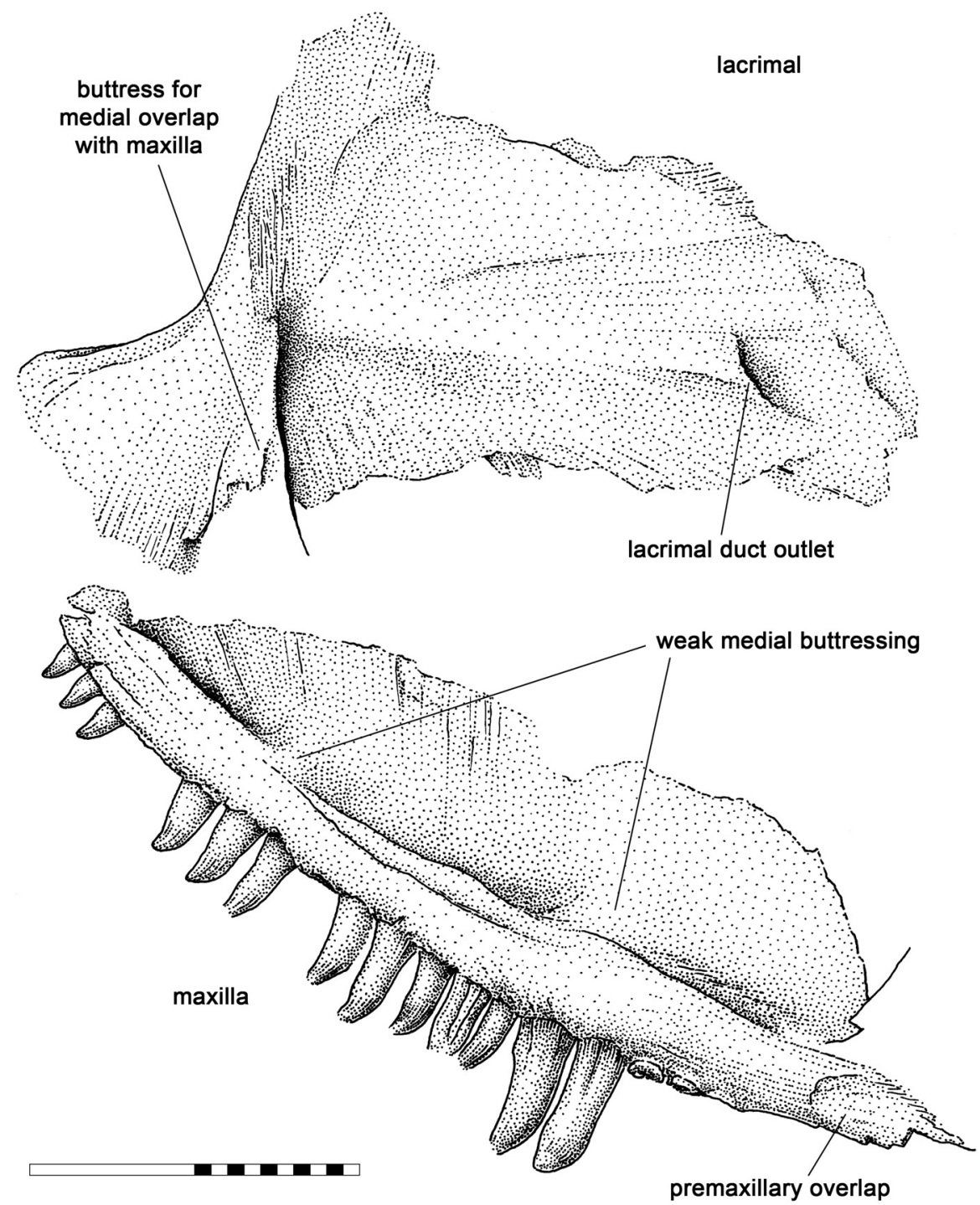

FIGURE 2. Interpretative drawing of ROM 43608, holotype of Kenomagnathus scottae, gen. et sp. nov., medial aspect of lacrimal and maxilla. Scale bar equals $2 \mathrm{~cm}$.

diastema result also in a superficial resemblance with Tetraceratops.

\section{DISCUSSION}

The distinctness of Kenomagnathus from all other Garnett synapsids of similar size (Kissel and Reisz, 2004; pers. obs. including unpublished material) is confirmed by different proportions and dentition patterns, instead of representing a case of ontogenetic decline of precanine tooth replacement (Eberth, 1985). lanthodon lacks the bulbous tooth type of other Garnett taxa illustrated in Figure 4 , but shares the lack of a weakly developed precanine step with Kenomagnathus.
The new genus Kenomagnathus possesses the oldest known diastema of all amniotes. To a limited extend, it closes a morphological gap between early Haptodontiformes and derived forms, such as Tetraceratops and certain Sphenacodontoidea. Considering the unique combination of the admittedly few observed characters, Kenomagnathus demonstrates that tooth row zonation occurred on various convergent trajectories within pelycosaur-grade synapsids.

The evolution of a functional diastema contributes to tooth row zonation, a general mosaic pattern in the evolution of synapsid's dentition. Therefore, a closer discussion of heterodonty pro- 

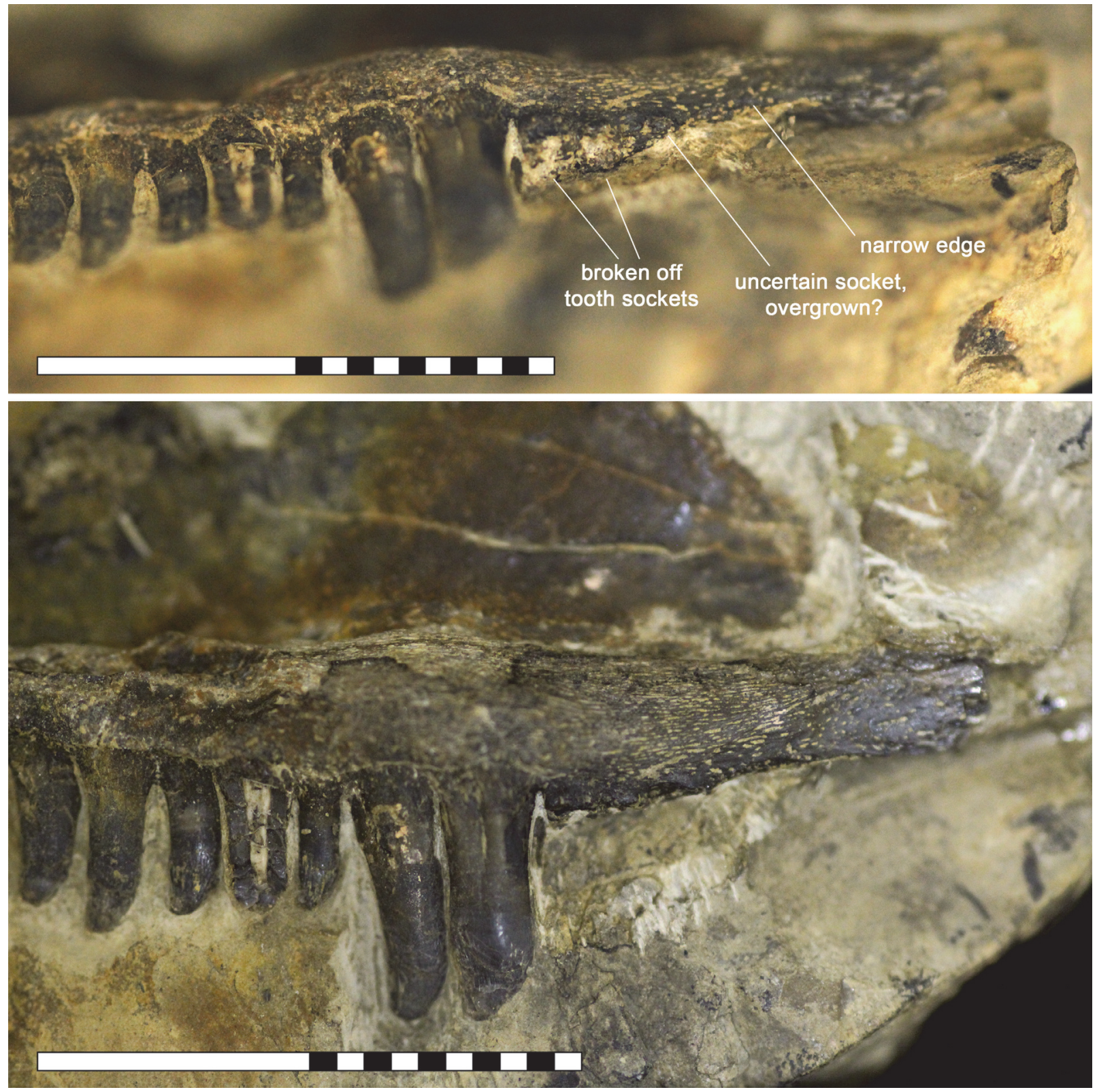

FIGURE 3. ROM 43608, holotype of Kenomagnathus scottae, gen. et sp. nov., close-up of anterior maxilla in medial aspect, from latero-ventral (above) and lateral (below). Scale bars equal $2 \mathrm{~cm}$.

vides a useful framework, with diastemata interpreted not as the absence, but an extreme of the modification of dentition. Among extant vertebrates, heterodonty is a common trait of mammals, as also observed in various other tetrapods (Melstrom and Irmis, 2019) and reversed in e.g. cetaceans. Mammalian heterodonty including well defined incisors, canines, premolars and molars is deeply nested within stem mammals, but with only initial and gradual origins among pelycosaur-grade representatives (Reisz et al., 2009). Although lacking postcanine zonation and only rarely exhibiting strongly differing tooth types, heterodonty is virtually ubiquitous among non-mammaliform therapsids (Sidor and Hopson, 1998). The presence of caniniform teeth or regions is found in Diadectomorpha, Eureptilia, rarely in Parareptilia (Berman et al., 2010; Clark and Carroll, 1973; Tsuji, 2006), and pelycosaur-grade early Synapsida. Double canines are typical of various early amniotes, reduced to a single canine per maxilla in Varanopidae and Therapsida (Spindler et al., 2018; Liu et al., 2009). Furthermore, there is variation in tooth size due to the position in the mouth and tooth 

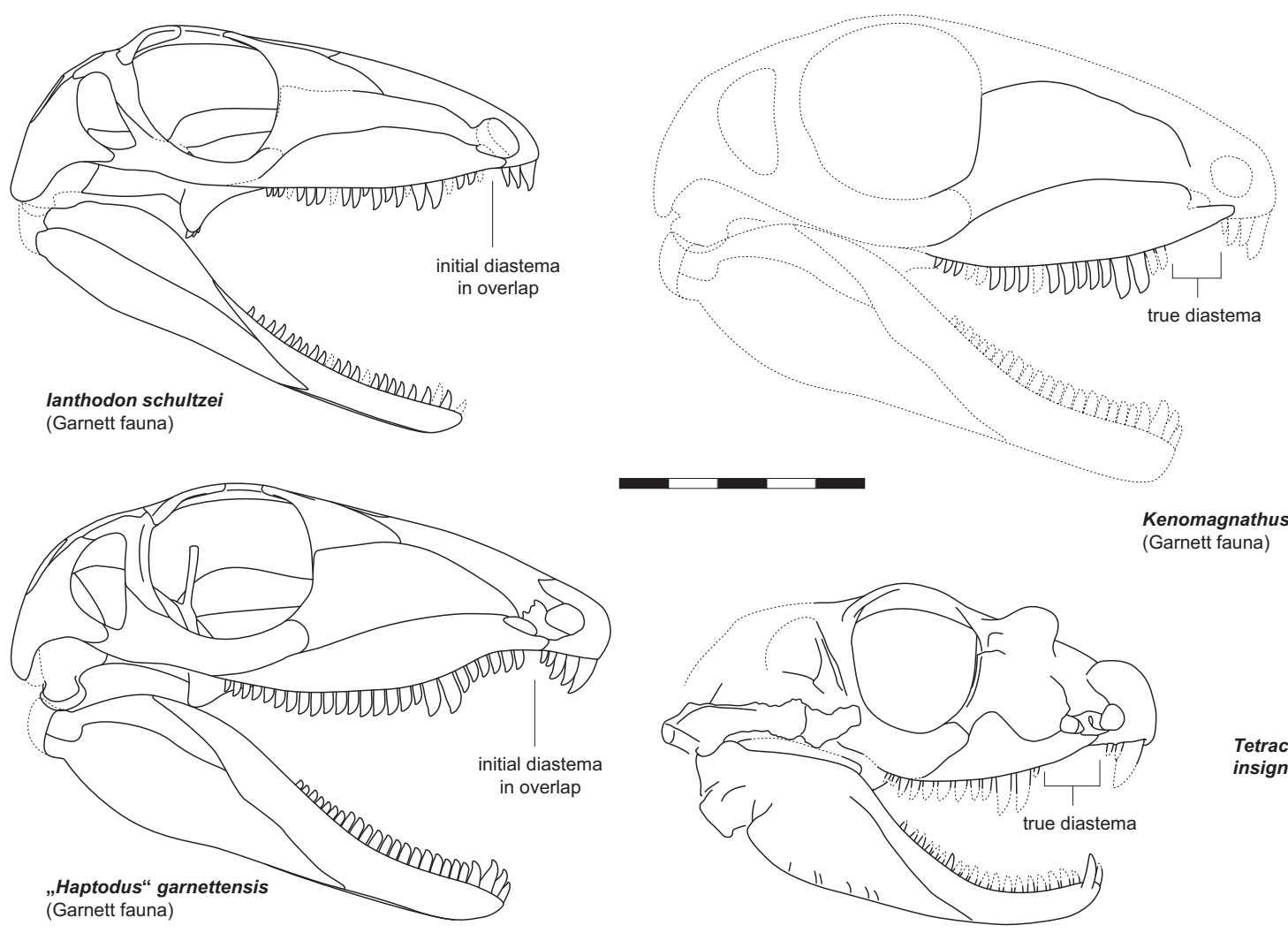

Kenomagnathus scottae
(Garnett fauna)
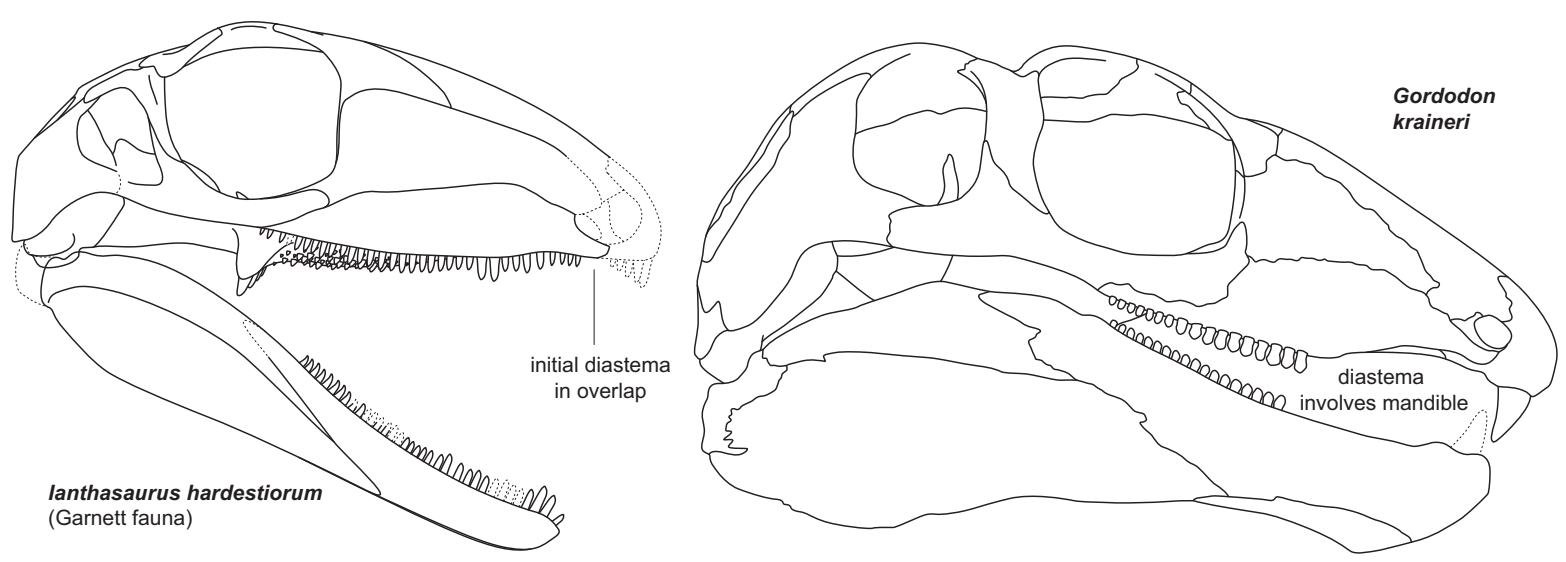

FIGURE 4. Skull reconstructions of chosen early synapsids with initial or functional diastemata. "Haptodus" garnettensis (immature size) is combined from best-known specimens, resulting from digital reconstructions. In comparison, Kenomagnathus scottae, gen. et sp. nov., has a deeper orbit and hypothetically deeper jaw. Own data, except for Gordodon (Lucas et al., 2018). Scale bar equals $5 \mathrm{~cm}$.

replacement (LeBlanc et al., 2017). Altogether, there is a gradual spectrum that hampers to unequivocally distinguish heterodonty from isodonty. Initial heterodonty (caniniform region, enlarged first premaxillary teeth) seems to represent a plesiomorphic condition for Synapsida or possibly Amniota as a whole, with the acquisition of isodonty being associated with insectivory (early
Varanopidae) or herbivorous adaptation (heterodont in terms of variation in tooth types, but isodont $=$ homodont when referring to only minor variation within a certain set of teeth; found in derived Caseidae, derived Edaphosauridae, and various therapsids). Zonation within the postcanine region occurs exceptionally (Eothyrididae, initially in Varanodontinae; possibly in Edaphosaurus, discussed by Spin- 
dler et al., 2019a). The condition ancestral to therapsids retains a rather unspecialized zonation in the context of early synapsids, as reported in Palaeohatteriidae or "Haptodus" garnettensis (not monophyletic with the type species $H$. baylei, Spindler, 2015). There is a morphological gap between their tooth-bearing precanine region and the therapsid dentition, in which a lack of precanine maxillary teeth is frequently associated with a considerable diastema. The latter is hardly indicative for a further step towards "mammalness", as it follows no obvious trend among non-mammalian therapsids and is rarely found in early representatives (King, 1988; Sigogneau-Russell, 1989; Sidor and Hopson, 1998, figure 1).

The recently discovered diastema and specialized dentition in the edaphosaurid Gordodon is tentatively interpreted as reflecting fructivorous habits (Lucas et al., 2018). Final clarification of its functional nature is probably impossible, since denticle pavement in the palate of edaphosaurids and other early amniotes has a certain but unknown role in food processing, likely corresponding to a modified tongue. Although dramatically increasing the morphological diversity of known pelycosaurgrade synapsids, Gordodon does not directly contribute to the evolution of dental zonation in the mammalian lineage beyond demonstrating a considerable plasticity in the jaw architecture. The occurrence of a dentary diastema is unique among early synapsids.

Functional morphology of sphenacodontian diastemata is apparently related to increased size of the lower caniniforms, which in contrast to upper canines or caniniforms are usually weakly developed, except in certain Ophiacodontidae (Stereorhachis) and Sphenacodontia (Sphenacodon, Dimetrodon, therapsids) (Spindler, 2019, figure 5). Lower canines are strengthened in Sphenacodontidae, in which they stand opposite to a maxillary diastema, which results from a pronounced precanine step (concave margin) and the reduction of precanine tooth numbers. It remains unclear which aspect in the sphenacodontid configuration (loss of teeth, precanine step, diastema) worked as the trigger in selection. That means, for example, that the diastema of some sphenacodontids might be a side effect from the precanine step when regular precanine teeth could not be grown any longer on the steeper margin (e.g., ontogenetically). Accommodation of the lower canines takes place more lingually, not in the same parasagittal plane as the diastema margin. This is also the case in therapsids, where no pronounced precanine step exists.
Probably, the formation of non-mammalian therapsid diastemata is linked to multiple factors, including the length of upper canines and feeding style, which could affect the lower canines regarding their range and interaction with the upper jaw. In any case, sphenacodontoid diastema are less comparable to those in Kenomagnathus, Gordodon, or Tetraceratops.

The incomplete formation of the diastema in Kenomagnathus with two remaining precanines suggests a still ongoing trend, assumably reflecting a stage that other diastema-bearing forms have gone through, regardless of the actual phylogenetic branch. Likely, the expansion of diastemata started at the premaxillary-maxillary overlap, which probably worked as an exaptation for the subsequent enlargement of lower caniniforms. This is suggested by the anatomical constraints in "Haptodus" garnettensis, lanthodon, and the early edaphosaurid lanthasaurus, where a tiny gap interrupts the otherwise continuing marginal tooth row around the area where the maxilla overlaps the premaxilla labially (Figure 4). This initial diastema is not an effect of tooth loss, but a minimal gap resulting from the stabilizing oblique facets where the dermal bones meet; the absence of tooth sockets could result from thin bone and possibly its local growth. Larger, functional diastemata evolved independently in Gordodon, Kenomagnathus, Tetraceratops, Sphenacodontidae, and Therapsida, but probably originated from a common anatomical, non-adaptive condition like in "Haptodus" garnettensis.

The evolutionary implications of Tetraceratops were recently re-evaluated (Spindler, 2020), confirming its pelycosaur-grade status and, thus, contradicting the widely known hypothesis of representing the oldest therapsid (Amson and Laurin, 2011). The clear diastema in Tetraceratops is not associated with a distinct precanine step, but prominent lower canines and reduced precanine dentition. The highly autapomorphic anatomy of this genus might imply a functional morphology that is very different from the spectrum of other early synapsids. In Tetraceratops, the diastema does not stand opposite to the lower canines, but follows posteriorly. Moreover, the extraordinarily shallow dentary tip implies that the enlarged first premaxillary teeth were still exposed when the mouth was closed. Although the pronounced diastema in Kenomagnathus implies any specialized use for food processing, comparisons to other early synapsida with this trait cover a wide spectrum of possibilities. 
A revised cladistic analysis is currently being prepared. Preliminary results for Kenomagnathus (Spindler, 2015) suggest a low position within Haptodontiformes, but this tree portion is poorly resolved. This results from the fragmentary nature of many Garnett specimens that hamper morphological overlap and recognition of potentially conspecific material, but also from the ecology of this assemblage. Various Haptodus-like taxa differ only slightly, mainly restricted to their dentition and skull proportions. Within this contemporaneous trophical nicheing of Garnett Haptodontiformes, Kenomagnathus might have performed a durophagous habit, suggested by its taller antorbital region. It is conceivable that the diastema was covered with rigid tissue in life and worked as an abutment for a cracking tooth (hypothetically enlarged lower canine). As potential prey, the paralic Garnett assemblage yielded crustaceans and bivalves (Moore et al., 1936; Reisz et al., 1982). In conclu- sion, the formerly overlooked uniqueness of the fragmentary specimen described herein contributes to the increasing understanding of early synapsid diversity, further supporting their early role as the dominant amniotes during the late Paleozoic (Kissel and Reisz, 2004).

\section{ACKNOWLEDGEMENTS}

I wish to express thankfulness for technical support and helpful discussions, appreciating D. Scott and R.R. Reisz (University of Toronto, Mississauga), J.W. Schneider and P.M. Sander (Technical University Bergakademie Freiberg, and Steinmann Institut, Bonn, respectively; DFG SCHN $408 / 20-1$ ), as well as M. Ferstl (trainee at the author's affiliation). The manuscript's quality benefits from the kind contribution of two anonymous reviewers.

\section{REFERENCES}

Amson, E. and Laurin, M. 2011. On the affinities of Tetraceratops insignis, an Early Permian syapsid. Acta Palaeontologica Polonica, 56(2):301-312. https://doi.org/10.4202/ app.2010.0063

Berman, D.S., Reisz, R.R., and Scott, D. 2010. Redescription of the skull of Limnoscelis paludis Williston (Diadectomorpha: Limnoscelidae) from the Pennsylvanian of Cañon del Cobre, Northern New Mexico.New Mexico Museum of Natural History and Science Bulletin, 49:185210.

Clark, J. and Carroll, R.L. 1973. Romeriid reptiles from the lower Permian. Bulletin of the Museum of Comparative Zoology, 144(5):353-407.

Currie, P.J. 1979. The osteology of haptodontine sphenacodonts (Reptilia: Pelycosauria). Palaeontographica Abt. A, 163:130?168.

Eberth, D.A. 1985. The skull of Sphenacodon ferocior, and comparisons with other sphenacodontines (Reptilia: Pelycosauria). New Mexico Bureau of Mines and Mineral Resources, Circular, 190:1-39.

King, G.M. 1988. Anomodontia, Handbuch der Paläoherpetologie, 17C. Gustav Fischer Verlag, Stuttgart.

Kissel, R.A. and Reisz, R.R. 2004. Synapsid fauna of the Upper Pennsylvanian Rock Lake Shale near Garnett, Kansas and the diversity pattern of early amniotes, p. 409-428. In Arratia, G., Wilson, M.V.H., and Cloutier, R. (eds.), Recent Advances in the Origin and Early Radiation of Vertebrates. Verlag Dr. Friedrich Pfeil, München.

Laurin, M. 1993. Anatomy and Relationships of Haptodus garnettensis, a Pennsylvanian synapsid from Kansas. Journal of Vertebrate Paleontology, 13(2):200-229. https://doi.org/ 10.1080/02724634.1993.10011501

LeBlanc, A.R.H., Brink, K.S., Cullen, T.M., and Reisz, R.R. 2017. Evolutionary implications of tooth attachment versus tooth implantation: A case study using dinosaur, crocodilian, and mammal teeth. Journal of Vertebrate Paleontology, 35:e1354006. https://doi.org/10.1080/ 02724634.2017 .1354006

Liu, J., Rubidge, B., and Li, J. 2009. 2009. New basal synapsid supports Laurasian origin for therapsids. Acta Palaeontologica Polonica 54(3):393-400. https://doi.org/10.4202/ app.2008.0071 
Lucas, S.G., Rinehart, L.F., and Celeskey, M.D. 2018. The oldest specialized tetrapod herbivore: a new eupelycosaur from the Permian of New Mexico, USA. Palaeontologia Electronica 21.3.39A:1-42. https://doi.org/10.26879/899 palaeo-electronica.org/content/2018/2343-new-eupelycosaur

Melstrom, K.M. and Irmis, R.B. 2019. Repeated evolution of herbivorous crocodyliforms during the age of dinosaurs. Current Biology, 29:2389-2395. https://doi.org/10.1016/ j.cub.2019.05.076

Moore, R.C., Elias, M.K., and Newell, N.D. 1936. A 'Permian” flora from the Pennsylvanian rocks of Kansas. Journal of Geology, 44(1):1-31.

Osborn, H.F. 1903. On the primary division of the Reptilia into two sub-classes, Synapsida and Diapsida. Science, 17(424):275-276.

Reisz, R.R., Berman, D.S., and Scott, D. 1992. The cranial anatomy and relationships of Secodontosaurus, an unsusual mammal-like reptile (Synapsida: Sphenacodontidae) from the early Permian of Texas. Zoological Journal of the Linnean Society, 104:127-184. https:// doi.org/10.1111/j.1096-3642.1992.tb00920.x

Reisz, R.R., Godfrey, S.J., and Scott, D. 2009. Eothyris and Oedaleops: do these Early Permian synapsids from Texas and New Mexico form a clade? Journal of Vertebrate Paleontology, 29(1):39-47. https://doi.org/10.1671/039.029.0112

Reisz, R.R., Heaton, M.J., and Pynn, B.R. 1982. Vertebrate fauna of Late Pennsylvanian Rock Lake Shale near Garnett, Kansas: Pelycosauria. Journal of Paleontology, 56:741-750.

Romer, A.S. and Price, L.W. 1940. Review of the Pelycosauria, Geological Society of America Special Papers, 28:1-538. https://doi.org/10.1130/spe28-p1

Sidor, C.A. and Hopson. J.A. 1998. Ghost lineages and "mammalness": assessing the temporal pattern of character acquisition in the Synapsida. Paleobiology, 24(2):254-273.

Sigogneau?Russell, D. 1989. Theriodontia I, Handbuch der Paläoherpetologie, 17B/I. Gustav Fischer Verlag, Stuttgart.

Spindler, F. 2015. The basal Sphenacodontia - systematic revision and evolutionary implications. Ph.D. thesis, Technische Universität Bergakademie Freiberg, Germany. http:// nbn-resolving.de/urn:nbn:de:bsz:105-qucosa-171748.

Spindler, F. 2016. Morphological description and taxonomic status of Palaeohatteria and Pantelosaurus (Synapsida: Sphenacodontia). Freiberger Forschungshefte C, 550(23):1-57.

Spindler, F. 2019. Re-evaluation of an early sphenacodontian synapsid from the Lower Permian of England. Earth and Environmental Science Transactions of the Royal Society of Edinburgh, 1-11. https://doi.org/10.1017/S175569101900015X

Spindler, F. 2020. The skull of Tetraceratops insignis (Synapsida, Sphenacodontia). Palaeovertebrata, 43(1):e1. https://doi.org/10.18563/pv.43.1.e1

Spindler, F., Voigt, S., and Fischer, J. 2019a. Edaphosauridae (Synapsida, Eupelycosauria) from Europe and their relationship to North American representatives. PalZ Paläontologische Zeitschrift (published online), https://doi.org/10.1007/s12542-019-00453-2

Spindler, F., Werneburg, R., Schneider, J.W. 2019b. A new mesenosaurine from the lower Permian of Germany and the postcrania of Mesenosaurus: implications for early amniote comparative osteology. PalZ Paläontologische Zeitschrift 93(2):303-344. https://doi.org/ 10.1007/s12542-018-0439-Z

Spindler, F., Werneburg, R., Schneider, J.W., Luthardt, L., Annacker, V., and Rößler, R. 2018. First arboreal 'pelycosaurs' (Synapsida: Varanopidae) from the early Permian Chemnitz Fossil Lagerstätte, SE Germany, with a review of varanopid phylogeny. PalZ Paläontologische Zeitschrift 92(2):315-364. https://doi.org/10.1007/s12542-018-0405-9

Tsuji, L.A. 2006. Cranial anatomy and phylogenetic affinities of the Permian parareptile Macroleter poezicus. Journal of Vertebrate Paleontology, 26(4):849-865. https://doi.org/ 10.1671/0272-4634(2006)26[849:caapao]2.0.co;2 